\title{
Produksi Garam Rakyat Berbasis Tuf Geomembran Di Kecamatan Samatiga Kabupaten Aceh Barat
}

\section{Production Salt People Based Tuf Geomembrane In Subdistrict Samatiga The District Of Aceh West}

\author{
Mahendra ${ }^{1}$ \\ ${ }^{1}$ Program Studi Akuakultur, Fakultas Perikanan dan Ilmu Kelautan Universitas Teuku Umar \\ Jl. Alue Peunyareng, Kecamatan Meureubo, Kabupaten Aceh Barat, Provinsi Aceh, 23615 \\ Korespondensi: mahendra@utu.ac.id
}

\begin{abstract}
ABSTRAK
Pengabdian ini bertujuan untuk meningkatka produksi garam di Kecamatan Samatiga. Permasalahan saat ini adalah Kebutuhan garam dengan kualitas baik di Indonesia masih mengandalkan impor dari luar negeri. Hal ini dikarenakan kualitas garam tersebut masih banyak yang dikelola secara tradisional yaitu dengan menggunakan cahaya matahari secara langsung. Untuk meningkatkan produksi garam dibutuhkan teknologi yang terbaru yang mampu mengembalikan produksi lahan yang rusak dengan cepat. Teknologi TUF Geomembran merupakan teknologi sangat efektif digunakan untuk reservoir. Selain geomembran, penggunaan ulir filter digunakan untuk mempercepat proses kristalisasi akan lebih cepat dan kualitas garam lebih putih serta tidak perlu pencucian garam. Hasil Produksi garam dengan teknologi ini hanya cukup 7-10 hari proses pengeringan menjadi kristalisasi dengan kualitas yang baik.
\end{abstract}

Kata Kunci: Garam, kualitas, TUF Geomembran

\begin{abstract}
Devotion is aimed to increase production salt in samatiga. Problems when it was a necessity of a salt with the quality of both in indonesia still rely on imported from foreign. It was because the qualities of a salt was still a lot of those managed in a traditional that is by using the light of the sun directly. To increase production salt needed latest technology able to return production land damaged quickly.Technology TUF geomembrane is technology is very effective used to a reservoir.Besides geomembran, the use of threaded filter used to fasten the process of crystallization will be quickly and the qualities of a salt whiter and not need to laundering salt.Produce a salt with that is only enough 7 to 10 the day the process drying be crystallization with good qualities.
\end{abstract}

Keyword: qualities, salt, TUF geomembrane

\section{PENDAHULUAN}

\section{Latar Belakang}

Garam merupakan salah satu jenis bahan pokok kebutuhan masyarakat yang sangat penting. Kebutuhan garam nasional dari tahun ke tahun semakin meningkat, namun jumlah produksinya justru mengalami penurunan. Kebutuhan garam dengan kualitas baik di Indonesia masih mengandalkan impor dari luar negeri. Hal ini dikarenakan kualitas garam tersebut masih banyak yang dikelola secara tradisional yaitu dengan menggunakan cahaya matahari secara langsung. Sehingga, untuk memenuhi kualitas garam yang baik harus diolah kembali untuk dijadikan garam konsumsi maupun industri.

Peningkatan produktivitas dan kualitas garam menjadi program utama untuk dapat memenuhi kebutuhan garam nasional yang mengalami peningkatan tiap 
tahunnya. Dengan menerapkan teknologi tepat guna dalam peningkatan produksi dan kualitas garam pada para pelaku produksi bahan baku garam, maka tidak hanya akan merebut pangsa pasar melainkan juga akan membantu dalam program swasembada garam. Oleh karena itu, setiap pelaku produksi bahan baku garam perlu melakukan penerapan teknologi tepat guna dalam hal peningkatan produksi dan kualitas garam.

Hasil FGD dengan mantan petani garam menyatakan bahwa sebelum tahun 2004, Kabupaten Aceh Barat merupakan daerah produksi garam rakyat secara traditional dengan menggunakan cahaya matahari langsung. Pasca-tsunami, lahan pertanian banyak yang mengalami kerusakan khusunya lahan pertanian garam. Secara tidak langsung, lahan pertanian banyak yang terlantar karena pemiliknya menjadi korban. Oleh karena itu, melalui program ini sentra produksi garam di Aceh barat bisa di terapkan kembali. Kendala terberat yang dihadapi oleh rakyat Aceh Barat adalah keterbatasan pengetahuan tentang peningkatan kualitas garam baik dari sisi sains, sisi teknologi, sisi perekonomian maupun sisi sumber daya berkualitas yang mengelolanya. Oleh karena itu, untuk meningkatkan produksi garam dibutuhkan teknologi yang terbaru yang mampu mengembalikan produksi lahan yang rusak dengan cepat.

\section{Tujuan Penelitian}

Tujuan teknologi geomembran ini adalah upaya menghindari kontak langsung antara dasar meja kristalisasi (tanah) dengan air laut yang akan dikristalkan dengan cara melapisi dasar meja kristalisasi dengan terpal plastik sehingga kualitas garam yang dihasilkan bebas dari kotoran/tidak bercampur dengan tanah.

\section{METODELOGI}

Teknologi geomembran adalah upaya menghindari kontak langsung antara dasar meja kristalisasi (tanah) dengan air laut yang akan dikristalkan dengan cara melapisi dasar meja kristalisasi dengan geomembran sehingga kualitas garam yang dihasilkan bebas dari kotoran/tidak bercampur dengan tanah. Selain geomembran, penggunaan teknologi ulir ini digunakan untuk mempercepat proses penuaan air, sehingga proses kristalisasi akan lebih cepat dan kualitas garam lebih baik. ulir dibuat berbentuk petakan - petakan yang berkelok - kelok untuk membuat arus air secara alami sehingga terjadi proses penguapan yang di bantu cahaya matahari dan angin. Ketinggian air pada ulir berkisar antara 5-10 cm. Disamping peningkatan kuantitas garam dengan teknologi ulir, peningkatatan kulaitas garam juga sangat diperlukan untuk meningkatkan harga jual garam. Setelah air tua di dapatkan, pada pintu air meja kristal dilakukan penyaringan menggunakan karbon aktif dan manganese green yang diletakkan dalam wadah filter. Di bagian bawahnya dibuat lubang untuk meminimalkan terbawanya kotoran dari laut. Karbon aktif yang terbuat dari batok atau tempurung kelapa yang dibakar berfungsi untuk mengikat bau dan gas beracun sedangkan manganese green berfungsi untuk menyerap kandungan besi (Fe) dan mangan ( $\mathrm{Mg})$, dimana batas aman garam untuk di konsumsi berkisar $<0,01 \mathrm{mg} / \mathrm{liter}$. 


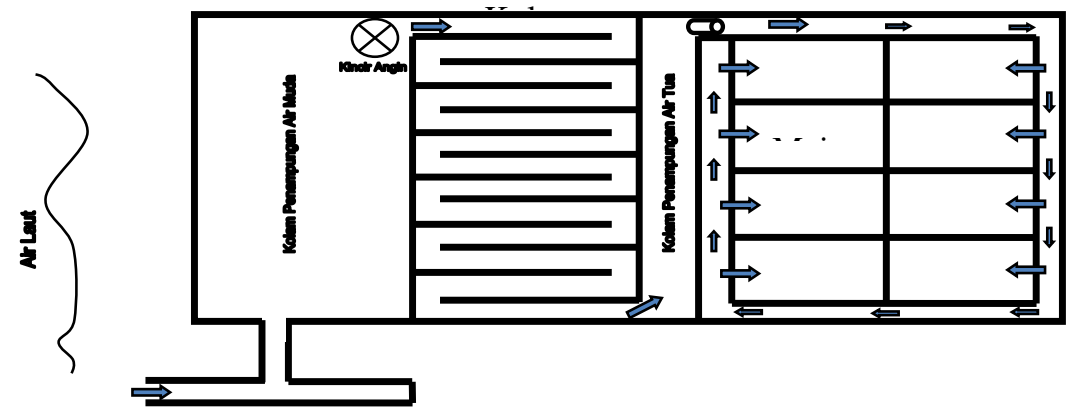

Gambar 1. Metode produksi garam rakyat dengan TUF geomembran

\section{HASIL DAN PEMBAHAN}

\section{Produksi Garam}

Tabel 1. Jenis garam dan harga yang dijual di pasar Meulaboh

\begin{tabular}{llccc}
\hline No & Jenis & $\begin{array}{c}\text { Harga sebelum } \\
\text { impor (Rp) }\end{array}$ & $\begin{array}{c}\text { Harga pasca } \\
\text { impor (Rp) }\end{array}$ & Asal \\
\hline 1 & Walet & 3000 & 4000 & Medan \\
2 & Dolpin & 3000 & 4000 & Medan \\
3 & Garam Yodium/ dapur & 1000 & 3000 & Medan \\
4 & Garam kasar Sigli & 6000 & 10000 & Sigli \\
\hline
\end{tabular}

Sumber: Harga jual pasar Aceh Barat

Data tersebut menunjukan bahwa peningkatan harga garam pasca impor meningkat. Hal ini berdampak bagi penjual dan pengolah ikan asin, dimana garam merupakan bahan baku utama dalam membuat ikan asin. Harga garam yang tinggi, akan membuat perekonomian di Samatiga akan melemah. Dengan adanya program produksi garam di Samatiga, diharapkan akan membantu dan meningkatkan perekonomian di Samatiga serta membantu dalam pemahaman ilmu dan teknologi khusunya dalam membuat garam. Dengan adanya sentral garam di Samatiga, akan membantu pembuat ikan asin, dimana selain harga yang murah juga masyarakat samatiga akan mampu membuat garam sendiri.

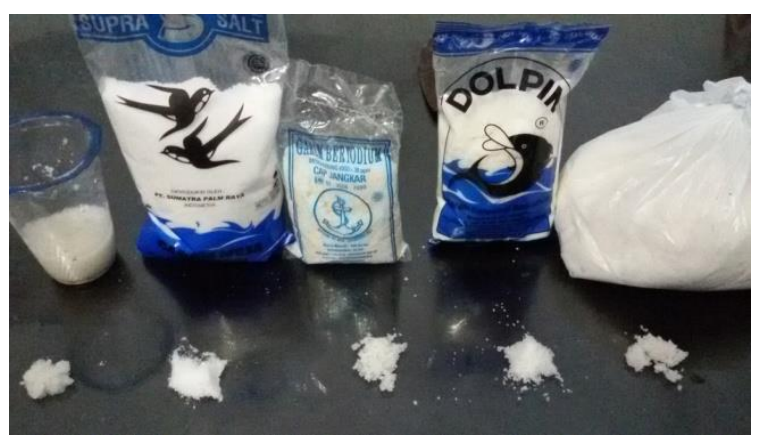

Gambar 2. Perbandingan garam produksi pabrikan dan produksi Kecamatan Samatiga

Berdasarkan hasil dilapangan, warga yang sudah mencicipi garam Samatiga mengatakan bahwa rasa garam tersebut sedap, dan sangat asin. Mereka juga mengatakan bahwa garam tersebut sangat cocok sekali sebagai bahan baku membuat 
ikan asin. Tekstur halus dan warna yang sangat putih, akan membuat prospek membuat garam di Samatiga menjanjikan di akan datang dan seterusnya.

Pembuatan garam dilakuan beberapa macam teknologi, dimana air laut sebagai sumber utama dalam membuat garam mengalir dalam pipa 3 inch dengam sistem gravitasi. Dimana air air laut mengalir mencari titik terendah. Setelah air mengalir. Air tersebut dinaikkan menggunakan kincir angin. Kincir angin akan menaikkan air laut ke kolam air laut muda. Air muda yang tersimpan di kolam penampung diendapkan selama $7-10$ hari dengan ketinggian air \pm 1 meter. Kolam ini juga berfungsi untuk mengendapkan kotoran yang terbawa oleh air laut, kemudian air dari kolam penampung dialirkan ke kolam ulir menggunakan kincir.

Air di kolam muda kemudian dialirkan ke kolam ulir. Air dari kolam penampungan air muda ke kolam ulir dialirkan menggunakan kincir angin. Kolam Ulir ini bertujuan untuk mempercepat proses penuaan air. dengan ketinggian air $5 \mathrm{~cm}$. Kepekatan ini akan cepat terjadi pada kolam ulir karena air tersebut selalu bergerak atau mengalir perlahan - lahan. Sebelum air mengalir ke kolam ulir, air tersebut disaring menggunakan karbon aktif dan manganese green dalam wadah filter. Fungsi bahan tersebut masing-masing adalah untuk mengikat bau dan gas beracun serta mengikat logam berat seperti zat besi dan mangan

Air hasil penuaan di kolam ulir kemudian ditampung di kolam penampung air tua. Kolam ini berfungsi untuk menyalurkan air tua ke meja Kristal. Kedalaman air tua di kolam ini sekitar $30 \mathrm{~cm}$. Air di kolam ini berfungsi sebagai stok air tua. Kepekatan air tua siap untuk dilepas ke meja Kristal. Air tua dari kolam penampungan menuju pintu air meja kristal dilakukan penyaringan menggunakan karbon aktif dan manganese green dalam wadah filter. Fungsi bahan tersebut masing-masing adalah untuk mengikat bau dan gas beracun serta mengikat logam berat seperti zat besi dan mangan.

Air tua selanjutnya dialirkan ke meja - meja kristal. Didalam meja Kristal air tua diendapkan selama 7 - 10 hari dengan kedalaman air $\pm 5 \mathrm{~cm}$. Seiring dengan lamanya waktu air tua akan mengkristal menjadi Kristal garam. Meja kristal ini dibuat dengan menggunakan geomembran. Teknologi ini digunakan dalam upaya menghindari kontak langsung antara dasar meja kristalisasi (tanah) dengan air laut dengan cara melapisi dasar meja kristalisasi dengan terpal plastik sehingga kualitas garam yang dihasilkan bebas dari kotoran/tidak bercampur dengan tanah.

Garam yang terbentuk di meja kristalisasi selama 7-10 hari selanjutnya dipanen dengan cara dikerik menggunakan alat pengerik yang terbuat dari kayu. Garam hasil panen kemudian dimasukkan kedalam karung dan selanjutnya diangkut ke gudang penyimpanan.

Kendala yang di hadapi adalah faktor cuaca seperti hujan. Faktor cuaca, di daerah sekitar meulaboh khususnya Kecamatan Samatiga sering hujan di sertai angin kencang pada bulan agustus, sehingga dalam pembuatan garam terkendala. Dengan demikian dalam pembuatan garam selanjutnya diharpakan pada bulan Maret dan April. Dimana pada bulan tersebut kosentrasi sinar matahari sangat tinggi dan curah hujan rendah. 


\section{PENUTUP}

\section{Kesimpulan}

Dari hasil pengabdian di simpulkan sebagai berikut:

1. Hasil Produksi garam dengan teknoligi TUF $g$

2. Eomembran dihasilkan selama 5-10 hari.

3. Bahan filter yang digunakan adalah karbon aktif dan Manganese green untuk menghilangkan bau, gas beracun dan menyerap zat besi dan mangan

4. Proses produksi garam dilakukan pada bulan januari samapai bulan Juli. Puncak Produksi pada bulan Maret dan April

\section{UCAPAN TERIMA KASIH}

Riset penulis dibiayai oleh Hibah Pengabdian Kepada Masyarakat dari DIKTI, dan ucapan terima kasih kepada Instansi Universitas Teuku Umar khusunya LPPM dan Penjaminan Mutu, Dekan Fakultas Perikanan dan Ilmu Kelautan serta Program Studi Akuakultur Fakultas Perikanan dan Ilmu Kelautan.

\section{DAFTAR PUSTAKA}

Badan Pusat Statistik. 2016. Badan Pusat Statistik Kabupaten Aceh Barat. Meulaboh Rachman ,A., D. Erfandi dam M.N.Ali. 2008. Dampak Tsunami Terhadap Sifat-Sifat Tanah Pertanian di NAD dan Strategi Rehabilitasinya. Balai Penelitian Tanah, Bogor.

Rahmawati, A. 2009. Efisiensi Filter Pasir-Zeolit Dan Filter Pasir-Arang Tempurung Kelapa Dalam Rangkaian Unit Pengolahan Air Untuk Mengurangi Kandungan Mangan Dari Dalam Air. FKIP Universitas Sebelas Maret. Surakarta

Sugiarti, I. 2013. Efisiensi Teknis Dan Ekonomis Teknologi Geomembran Pada Produksi Garam Tambak Di PT.Garam II Pamekasan Dan Prospek Pengembangan Di Tingkat Petani. Program Studi Agribisnis. Fakultas Pertanian. Universitas Jember. Jember

Tinning, G. 2007. Agriculture After The Tsunami Aceh Dan Di Luar Negeri. Australian Government. Australian Centre For International Agricultural Research. Australia

Wahyunto., S.Ritung, F.Agus, dan W.Wahdini. 2008. Pilihan Tanaman Pertanian Untuk Kabupaten Aceh Barat, Provinsi Nanggroe Aceh Darussalam. Balai Penelitian Tanah. Bogor

Zulfiadi. 2014. Permukiman Kembali Pasca Bencana Tsunami Di Desa Kuala Bubon Kecamatan Samatiga Kabupaten Aceh Barat. Universitas Gadjah Mada. Yogyakarta 